Scientific Review - Engineering and Environmental Sciences (2018), 27 (3), 260-268

Sci. Rev. Eng. Env. Sci. (2018), 27 (3)

Przegląd Naukowy - Inżynieria i Kształtowanie Środowiska (2018), 27 (3), 260-268

Prz. Nauk. Inż. Kszt. Środ. (2018), 27 (3)

http://iks.pn.sggw.pl

DOI 10.22630/PNIKS.2018.27.3.25

Piotr NOWOTARSKI, Jerzy PASŁAWSKI

Faculty of Civil and Environmental Engineering, Poznan University of Technology

\title{
Lean management in small and medium-sized construction enterprises in Poland - selected results*
}

Key words: lean management, lean construction, SMEs, construction companies, continuous improvement, surveys, questionnaires

\section{Introduction}

The idea of continuous improvement is getting more and more popular in the global economy. More companies are starting to notice the need to improve the quality of products, improve working conditions and reduce overall wastage. One of the key concepts that could help in this pursuit is lean management methodology which is applied in many sectors at different stages of the productions process.

Research related to the check of the use of improvement tools in small and medium-sized companies in construction sector are not so popular and not many researchers take up the topic, which is why the authors of this article see the need to analyze this area. Especially interesting seems to be the possibility of checking if companies use any training for improving qualification of its employees, because only well qualified crew can be base for new implementations and development. What is more, getting to know if staff had contact with ideas such as lean management also could indicate if companies and employees are open for new techniques and methods improving inside situation and flow of the processes. Interesting from the research perspective would be also finding the information how efficiency is assessed by people involved in the construction process.

Above-mentioned aspects are key motivators by which authors were guided in preparation of this article, and they are an important step in the direction of popularization of improvements methods and techniques such as lean management especially in small and medium-sized enterprises sector, which pays crucial role in the global economy (Moreno \& Casillas, 2008).

*The publication was created as part of the statutory activities of the Institute of Structural Engineering and ConInno Academic Association at Poznan University of Technology. 


\section{Lean management idea}

Lean management is an idea identified with the management, which has direct correlation with Toyota Production System - TPS (Al Manei, Salonitis \& $\mathrm{Xu}, 2017)$. It was first utilized by Krafcik in the article which discussed the outcomes of an international study on the automotive industry, which was related with the search for the reasons for prevalence of the Japanese constructors delivering cars utilizing traditional management strategies over different nations (Krafcik, 1988).

The fundamental idea of lean management is associated with the diminishment of waste (Tamjidillah \& Santoso, 2017) in places where it is conceivable, and orientation to creation of added value for the end customer (Brioso, 2015), which is implemented through an assortment of strategies presented at the phase of arranging and production of the product. In the literature (Kadarova \& Demecko, 2016; Plebankiewicz \& Mitera, 2016) eight main types of waste are described which could be with the help of the lean management relatively easily detect and later eliminated: overproduction, waiting, over-processing, transportation, storage, unnecessary movement, defects, non-utilized talents.

All of them can be observed also during performance analysis of the construction processes, so it can be said that lean approach is getting more and more widely used in construction nowadays (Shakeri, Boroujeni \& Hassani, 2015). At the same time more often those methodology and related methods are applied to improve the implementation of other, crucial from the construction point of view, measures in areas such as: health and safety (Pasquire \& Gibb, 2009) and building information modeling - BIM (Sacks, Koskela, Dave \& Owen, 2010), with the use of the assessment of, among others, elements of fuzzy logic known for example from the production (Vinodh \& Aravindraj, 2013). Figure 1 presents lean management development based on integration with new trends observed in literature.

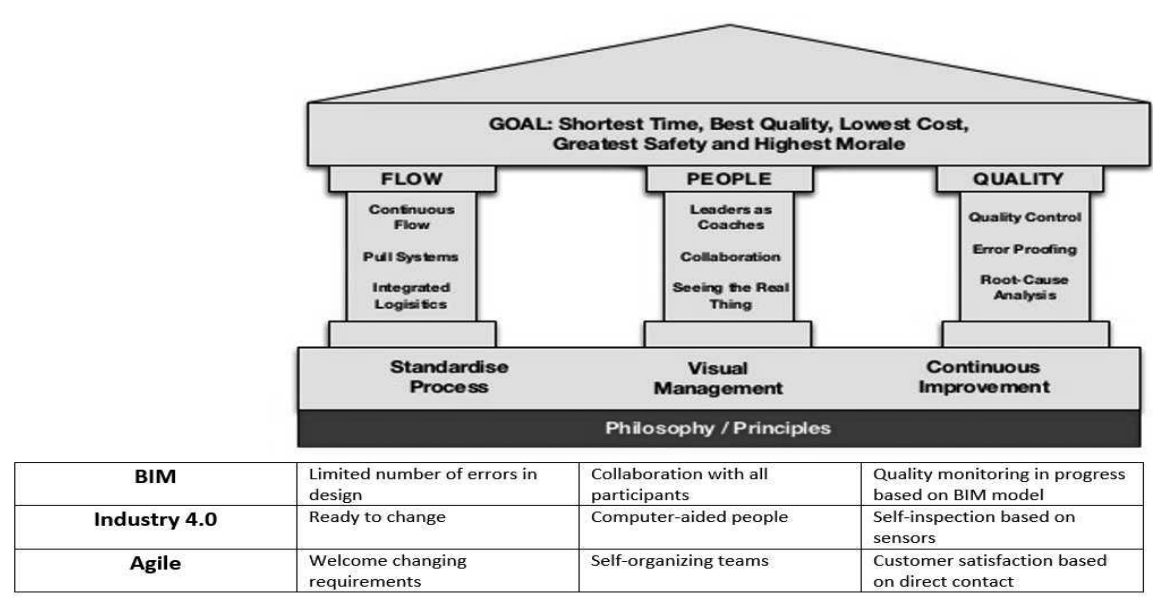

FIGURE 1. Lean management development based on integration with new trends (own elaboration based on materials Lean.org) 
It ought to be noted that in Poland the origins of lean management and the idea of lean thinking used in the construction should be, according to the authors, dated back to 2003, when a team led by Sobotka noted and described the relationship between the listed methods and total quality management - TQM (Sobotka, Biruk \& Jaśkowski, 2003).

\section{Lean construction in Poland}

In Poland, the topic of lean management is addressed to a large extent by people involved in the analysis of production and manufacturing processes, which is understandable in the historical aspect, as the first attempts to streamline processes concerned precisely this branch of the economy.

Polish researchers realizing the subject of lean management introduction, apart from the implementation examples, also work on the application of various lean management methods in enterprises used as part of surveys among entrepreneurs. The publication by Stadnicka and Antosz (2013) is a source of more interesting data, where large companies were subjected to research. The conclusions that have been put forward show that even large companies do not have any lean management system implemented, and some of the most common methods are those related to 5S (a tool whose goal is to create and maintain a well-organized and safe workplace) and standardization of work and activities performed by employees.

Researchers in their works also focus on the SME's sector, although it is not necessarily directly related to the con- struction market, or there is no mention about it. Helman (2012), and Migza and Bogacz (2015) are analyzing the possibility of applying the lean management methodology in i.e. mining sector enterprises. Chomątowska and Żarczyńska-Dobiesz team (2014) showed the possibilities of eliminating waste on two examples of medium and large production enterprises. Selected lean management techniques in a small production enterprise were considered by Kisiel (2014) in the aspect of the possibility of introducing the $5 \mathrm{~S}$ method and the SMED (single minute exchange of die) technique - quick retooling, which was also dealt in in his research by Bednarek and Buczacki (2014). An interesting review of lean tools used in Polish foundries was prepared by the team Jezierski and Janerka (2013), who showed that only $29 \%$ of such enterprises in Poland use any lean management tools.

The above-mentioned positions are treating in general on the issues related to research on SMEs, as they are not oriented on the smallest companies which is creating a knowledge gap important from the author's point of view, which requires completion.

Analyzing the problems of lean management and construction, it should be noted that one of the first studies carried out in the field of SMEs for lean management concerned the scope of application of this methodology in manufacturing enterprises carried out Walentynowicz (2013). A total of eight enterprises were examined, of which five belonged to the SME sector and one was related to construction. The research was interesting because it was decided to check the following research hypothesis: in a pro- 
duction company, the greater the possibility of applying the lean management concept in full form, the specificity of its functioning is closer to the specifics of the automotive industry (the prototype of this concept) Finally, the research hypothesis was confirmed paying attention to a very important variable, which depended on the level of depth and the scope of application of the lean management concept in the company. It has been shown that the competences of implementing persons are the most important factor that influences the results of the implementation of the concept.

Antosz and Stadnicka (2017) conducted research on the implementation of the lean management idea in the SME's sector in Poland. Various ways of implementing this philosophy by enterprises have been examined. The research was carried out among entrepreneurs representing various fields of the economy from the Podkarpackie Voivodeship (Poland). The detailed research topic concerned: reasons for using lean management, main lean objectives, implementations, type of wastes, Lean implementation objectives, implementation assessments and their measures, techniques and problems during deployments, techniques used. The study used a questionnaire in the form of multiplechoice questions with the possibility of adding own comments. The research was carried out on a group of 49 companies, including metal processing, paper industry, chemical industry, aviation, automotive industry, construction industry and others. The size of the companies participating in the survey are medium-sized companies $53 \%$, small $-33 \%$ and micro $-14 \%$. It should be noted that compa- nies from the construction sector were only 4.

The results of Antosz's and Stadnicka's (2017) works show that a significant part of SMEs are ready to implement the lean management philosophy, but the majority $(55 \%)$ do not carry out these activities. Most introductions are observed using the $5 \mathrm{~S}$ method $(29 \%)$. In addition, the main motivations associated with the implementation of these methods are the intention to improve the functioning of the company $(81 \%)$ and the need to gain a competitive advantage $(50 \%)$. The wastage reported in the summary mainly concerned expectations for material (49\%), unnecessary movements (41\%) and machine breakdowns (39\%).

The selected articles related to the introduction of lean management in enterprises of the SME's sector in terms of the construction market in Poland show that there is a gap of knowledge in the field of research on the implementation of the mentioned methodology in the construction sector in Poland. First of all, the previous studies presented above were not directed directly at construction. It should be noted that some of the works contained some of the information on construction, but their main goal was to present a more general scope of lean management solutions introduced, hence the subject matter finds its place and responds to the real needs of SMEs in construction companies.

\section{Material and methods}

Authors decided to perform survey on the small medium and construction companies workers. It was part of work 
related to bigger project which is connected with $\mathrm{PhD}$ thesis of one of the authors. The purpose of the questionnaire was to gather feedback about the current situation of the construction sector companies in terms of improvement methods, lean management application and knowledge as well as supporting lean management tools (real time locating systems and trainings) with the focus on the smallest companies - micro, small and medium.

There were totally 217 surveys analyzed, which were conducted in the digital form using google questionnaires system. Questionnaires itself consisted of several parts that included introduction with the explanation of the aim of survey, questions related to the company, position held, lean management general knowledge, lean management methods, a

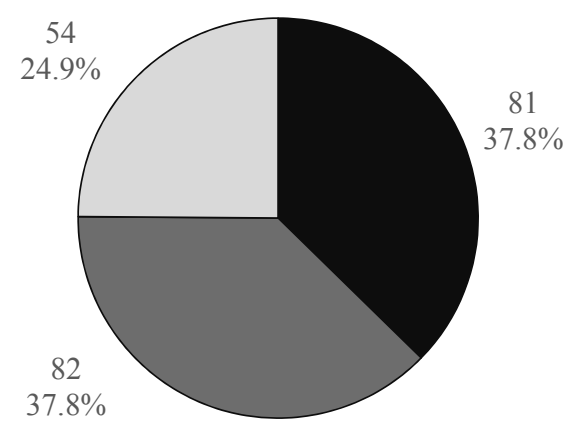

-Micro $\square$ Small $\square$ Medium use of tracking systems in the enterprise and information on any interest in participating in lean management training. It was prepared in two languages - to broad the possibility of gathering answer also from people speaking English more fluently than Polish.

\section{Selected study results}

For better understanding of the background of the current situation, information related to the type fo the surveyed company, number of employees in each compay and comapny operation range is presented in Figures 2 and 3.

There were totally 217 answers analyzed out of which $24.9 \%$ came from medium-sized companies, $37.3 \%$ from

b

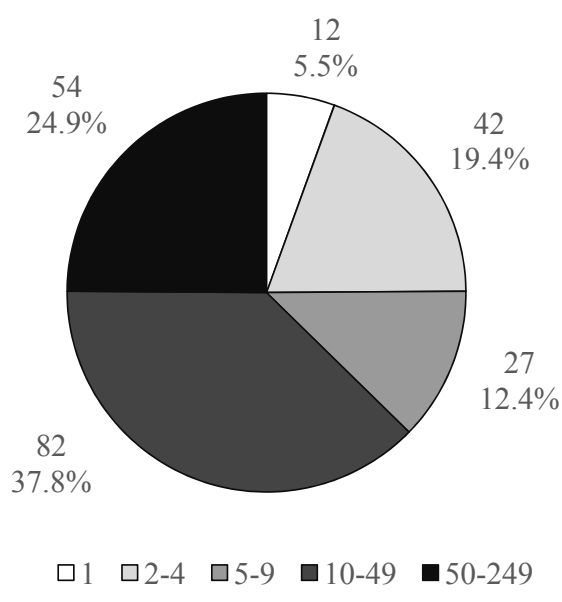

FIGURE 2. Types of surveyed companies (a) and number of employees in each company (b) (own studies)

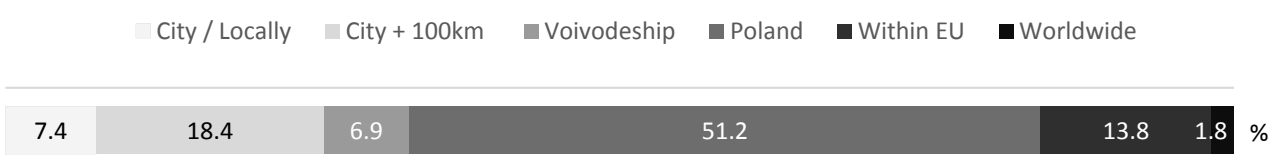

FIGURE 3. Companies operation range (own studies) 
micro and $37.8 \%$ from small. Within the micro firms, 12 where one-person business activity, in 42 there were 2-4-persons employed and 27 had crew of 5-9 people.

The majority of companies $(51.2 \%)$ have its operation range set within the Polish area. Exectly $7.4 \%$ operates locally and what is interesting in the survey participated also employees from companies working on the EU market $(13.8 \%)$ as well as on global market (1.8\%).

It can be said that in the survey there was full representation of companies taken into account employing between 1 and 249 people and operating on different markets, starting locally and finishing globally.

Results of question analysis connected with trainings which are related to process flow and working conditions are presented in Figure 4. From the presented graph in can be easily concluded that the best situation is present in medium companies, where cyclical or occasional trainings are organized by employer in $66.6 \%$ cases. The worst situation is in micro sector, because only $32.1 \%$ of people participate in such courses. This clearly represents so-called accessibility level to trainings, which is definitely higher for bigger companies and can be connected with organization structure of the company (possibility of replacing trainee employee).

Contact with lean management methodology question results are presented in Figure 5.

Results showed that there is limited amount of people who are or were using lean management methodology in their work respectively for medium, small and micro companies: 3.8, 2.4 and $6.2 \%$. Some of the respondents have heard about it $-44.4 \%$ in medium-sized, $46.3 \%$ in small and only $27.2 \%$ in micro companies. However, majority did not know what the lean management is, about of which the biggest group was micro companies, where $66.7 \%$ declared lack of knowledge about it.

This result confirms that access to the information related to the newest management methods, in this case lean

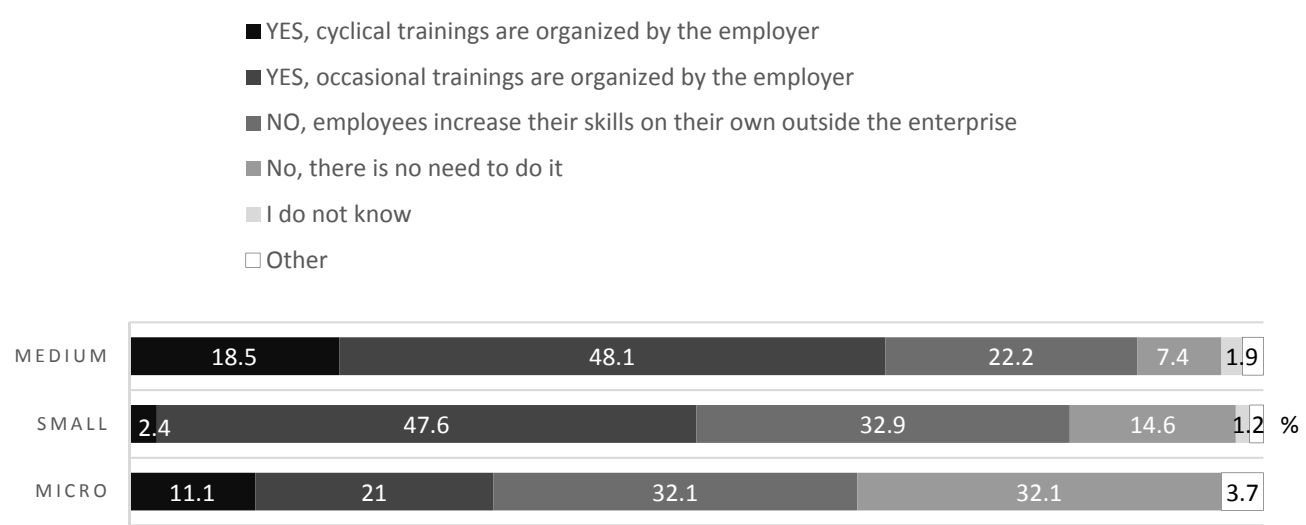

FIGURE 4. Question results connected with training related to process flow and working condition results (own studies) 


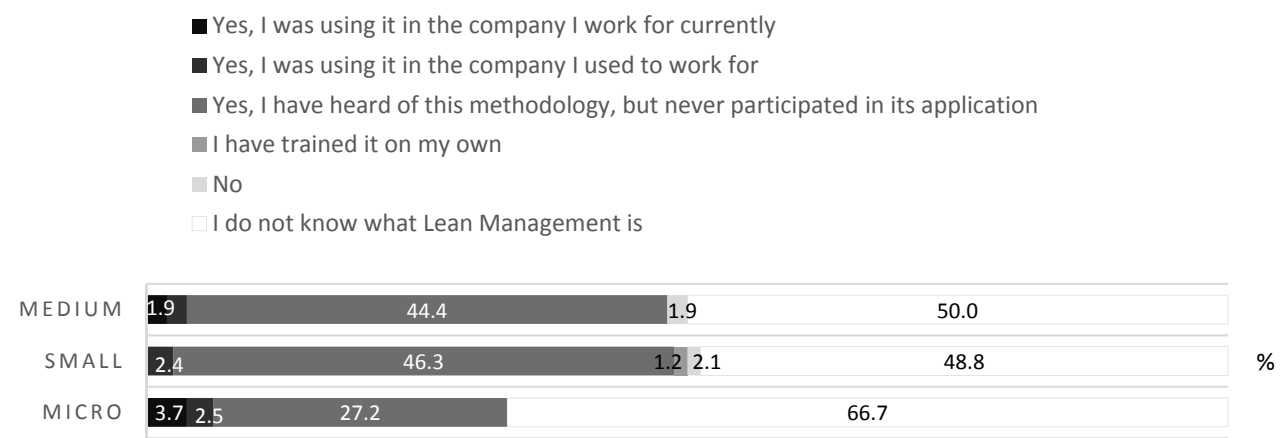

FIGURE 5. Question results connected with contact with lean management methodology



FIGURE 6. Question results connected with efficiency assessment of lean management

management, is the lowest in the smallest companies. What is more general awareness regarding surveyed topics in whole SME sector is low, and there is definitely place for informative, educative, training actions related to spreading knowledge on benefits of using new management methods in this sector.

Efficiency assessment of lean management according to responders is presented in Figure 6. Presented figures confirmed, that due to the lack of knowledge majority of responders $(80 \%)$ were not able to asses it, due to the limited contact with this methodology. Within people who manage to asses it, majority was pointing high and medium efficiency of this management method. This confirms thesis that when companies know how to use lean management it becomes powerful tool with impact on the involved processes, especially with the connection with other methods.

\section{Conclusions}

Presented literature review on the lean management application in construction sector, as well as analyzed results of own studies based on 217 survey responses allows to draw the following conclusions:

1. So far there were not carried out comprehensive research on impact of new management methods (lean management) in construction with the focus on SME sector.

2. Accessibility level to trainings related to process flow and organization of place of work, is much higher for bigger companies and it is probably connected with organization capabilities.

3. Access to the information related to newest management methods, in this case lean management, is the lowest in the smallest companies. 
4. General awareness regarding lean management in whole SME construction sector is low, and majority of responders had no contact with this method.

5. Responders familiar with analyzed methods pointed high and medium efficiency of when assessing lean management, what confirms general positive effects of this techniques.

Study showed that there is still place for further examination of lean management introduction in construction sector, and the authors are planning to take care of this area while working on $\mathrm{PhD}$ as well as carrying further work in this area, especially taking into account lean management synergy with other new management methods.

\section{References}

Al Manei, M., Salonitis, K. \& Xu, Y. (2017). Lean implementation frameworks: the challenges for SMEs. Procedia CIRP, 63, 750-755.

Antosz, K. \& Stadnicka, D. (2017). Lean philosophy implementation in SMEs - study results. Procedia Engineering, 182, 25-32.

Bednarek, M. \& Buczacki, A. (2014). Lean Manufacturing (LM) Practical Application in a Selected Polish Company. Ekonomika i Organizacja Przedsiębiorstwa, 11, 100-101.

Brioso, X. (2015). Integrating ISO 21500 Guidance on Project Management, Lean Construction and PMBOK. Procedia Engineering, 123, 76-84.

Chomątowska, B. \& Żarczyńska-Dobiesz, A. (2014). Elimination of waste in production enterprises - case studies. Research in Logistics \& Production, 4(2), 157-166.

Helman, J. (2012). Analysis of the potentials of adapting elements of Lean methodology to the unstable conditions in the mining industry. AGH Journal of Mining and Geoengineering, 36(3), 151-157.

Jezierski, J. \& Janerka, K. (2013). The Lean Manufacturing tools in Polish foundries.
Archives of Metallurgy and Materials, 58(3), 937-940.

Kadarova, J. \& Demecko, M. (2016). New Approaches in Lean Management. Procedia Economics and Finance, 39, 11-16.

Kisiel, P. (2014). Analiza możliwości wdrożenia wybranych technik Lean Management w przedsiębiorstwie produkcyjnym. Logistyka, 6, 5457-5464.

Krafcik, J.F. (1998). Triumph of the lean production system. MIT Sloan Management Review, $30(1), 41$.

Migza, M. \& Bogacz, P. (2015). Możliwość wykorzystania narzędzi Lean Management w przedsiębiorstwach sektora górnictwa podziemnego w Polsce. Przegląd Górniczy, $71,58-61$.

Moreno, A.M. \& Casillas, J.C. (2008). Entrepreneurial orientation and growth of SMEs: A causal model. Entrepreneurship Theory and Practice, 32(3), 507-528.

Pasquire, C.L. \& Gibb, A.G. (2009). A lean and agile construction system as a set of countermeasures to improve health, safety and productivity in mechanical and electrical construction. Lean Construction Journal, 1, 61-76.

Plebankiewicz, E. \& Mitera, E. (2016). Źródła marnotrawstwa na budowie. Materiaty $\mathrm{Bu}$ dowlane, 6, 184-185.

Sacks, R., Koskela, L., Dave, B.A. \& Owen, R. (2010). Interaction of lean and building information modeling in construction. Journal of Construction Engineering and Management, 136(9), 968-980.

Shakeri, I., Boroujeni, K. A. \& Hassani, H. (2015). Lean Construction: From Theory To Practice. International Journal of Academic Research, 7(1), 129-136.

Sobotka, A., Biruk, S. \& Jaśkowski, P. (2003). Zarzqdzanie $w$ budownictwie. Lublin: Wydawnictwa Uczelniane Politechniki Lubelskiej.

Stadnicka, D. \& Antosz, K. (2013). Lean in large enterprises: Study results. World Academy of Science. Engineering and Technology, 82, 31-37.

Tamjidillah, M. \& Santoso, P.B. (2017). The model relationship of wastes for parameter design with green lean production of fresh water. Scientific Review - Engineering and Environmental Sciences, 26(4), 481-488. 
Vinodh, S. \& Aravindraj, S. (2013). Evaluation of leagility in supply chains using fuzzy logic approach. International Journal of Production Research, 51(4), 1186-1195.

Walentynowicz, P. (2013). Zakres zastosowania Lean Management $w$ przedsiębiorstwach produkcyjnych - wyniki badań empirycznych. Opole: Oficyna Wydawnicza Polskiego Towarzystwa Zarządzania Produkcją.

\section{Summary}

Lean management in small and medium-sized construction enterprises in Poland - selected results. Research related to the check of the use of improvement tools in small and medium-sized companies in construction sector are not so popular and not many researchers take up the topic. Article presents the survey results on group of
217 small and medium-sized enterprises regarding lean management method use, knowledge and efficiency assessment. Presented results showed among others that there is a need for smaller companies to focus on gaining actual knowledge about new management methods that could improve their efficiency and workflow, and that there is still place for further examination of lean management introduction especially in construction sector.

\section{Authors' address:}

Piotr Nowotarski, Jerzy Pasławski

Politechnika Poznańska

Wydział Budownictwa i Inżynierii Środowiska Instytut Konstrukcji Budowlanych pl. M. Skłodowskiej-Curie 5, 60-965 Poznań Poland e-mail: Piotr.nowotarski@put.poznan.pl 